\title{
CPU 冷却向けループ式熱サイホンの傾斜によるドライアウト発生について
}

\author{
豊田 浩之*1，近藤 義広*1，佐藤 重匡*2，椿 繁裕 ${ }^{* 2}$, 平澤 茂樹*3
}

\author{
Study on dry-out occurrence in inclined loop thermosyphon for CPU cooling \\ Hiroyuki TOYODA ${ }^{* 1}$, Yoshihiro KONDO ${ }^{* 1}$, Shigemasa SATO ${ }^{* 2}$, Shigeyasu TSUBAKI ${ }^{* 2}$ \\ and Shigeki HIRASAWA ${ }^{* 3}$

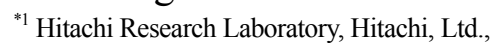 \\ 832-2 Horiguchi, Hitachinaka-shi, Ibaraki 312-0034, Japan \\ ${ }^{* 2}$ Information and Telecommunication Systems Company, Hitachi, Ltd., \\ 1 Horiyamashita, Hadano-shi, Kanagawa 259-1392, Japan \\ ${ }^{* 3}$ Dept. of Mechanical Engineering, Kobe University \\ 1-1 Rokkodai-cho, Nada-ku, Kobe 657-8501, Japan
}

\section{Received 11 July 2014}

\begin{abstract}
A loop thermosyphon is known to have a higher heat transfer performance without a pump. In addition, there is demand for the reduction of the electricity needed for the fan used to cool the CPUs in a rack mount server. We more efficiently designed a new loop thermosyphon that is thinner and applicable to rack mount servers. Thermosyphon uses gravity to return the refrigerant from the condensation part to the boiling part of the system. Therefore, when it is in operation, the water level in the condenser should be higher than that in the evaporator. However, it is slightly more difficult to ensure the water level differences in such a thin loop thermosyphon than the thick one. The dry-out which is the phenomenon that refrigerant does not return to the boiling part is easy to occur, when the loop thermosyphon is inclined and there is less refrigerant in it. Therefore, it is important to clarify the relationship between the angle needed to start the dry-out and the refrigerant enclosure quantity. For this purpose, we conducted experimental measurements while changing the conditions, and showed that the dry-out angles could be estimated by using a geometric water surface model, which is combined with the calculation of the pressure drop in a vapor tube and the calculation of the steam temperature based on the water surface level in the condensation tube. As a result of using this model, we confirmed that the length of the vapor tube and the volumetric capacity of the bottom header affect the dry-out angle.
\end{abstract}

Key words : Thermosyphon, Boiling, Condensation, Dry־out, Heat transfer, CPU cooling

\section{1. 緒言}

電子機器の高性能化や省電力化に対する需要の高まりに伴い，その冷却システムにも高性能化や省エネルギー 化が求められている. 特にサーバ機器においては, 冷却に必要なファンの電力を極力小さくすることが重要であ る.このために高発熱部品である CPU（Central Processing Unit）に取り付けられるヒートシンク自体の性能向上 が求められている，サーバ内でヒートシンクの占有するサイズを変えることなく性能を向上させるためには，冷 媒の相変化を利用した熱輸送が有効であり，その一つとして環境への影響がない水を冷媒に用いた熱サイホンの 適用がある(Webb and Yamauchi, 2002). 単管を用いた熱サイホンは，同一管内で蒸気の流れと液冷媒の流れが対向 するフラッディングにより，最大熱輸送量が制限されることが研究されている(門出他，1995) (Inoue and Monde, 2009). これに対して, ループ式熱サイホンは, 蒸気管と水戻り管を別としたループ状の流路となっておりフラッ

No.14-00369 [DOI: 10.1299/transjsme.2014tep0368]

${ }^{* 1}$ 正員, (株) 日立製作所 日立研究所（厂312-0034 茨城県ひたちなか市堀口 832-2）

*2 (株) 日立製作所 情報・通信システム社（广259-1392 神奈川県秦野市堀山下 1)

*3 正員, フェロー, 神戸大学 工学研究科（干657-8501 兵庫県神戸市灘区六甲台町 1-1）

E-mail of corresponding author: hiroyuki.toyoda.qr@hitachi.com 
Toyoda, Kondo, Sato, Tsubaki and Hirasawa, Transactions of the JSME (in Japanese), Vol.80, No.820 (2014)

ディングによる熱輸送への制限はなく, 発熱量の大きな機器の冷却にも有利である.ループ式熱サイホンの CPU 冷却への利用については, 沸騰を促進する構造のものが開発され, その熱抵抗が従来の冷却システムと比較して 低くなることが示されている(儀間他, 2004). さらに, 著者らは冷媒に水を用いた CPU 冷却向けループ式熱サイ ホンを高さ $2 U$ のラックマウントサーバ機器へ適用し(豊田他, 2011)，不凝縮ガスと性能の関係を明らかにした (豊田他, 2012).ここでU は標準ラックマウントサーバの高さの単位であり，1U は約 $44.5 \mathrm{~mm}$ である. サーバ装 置内部に実装寸るために，ループ式熱サイホンの高さを $67.4 \mathrm{~mm}$ に抑えた点が特徴の一つである. 一般にループ 式熱サイホンは重力の作用で泠媒を循環させるため, 冷媒循環に伴う圧力損失と釣り合うように，沸騰部側より も凝縮部側の液面が高くなければならない. 本ループ式熱サイホンは, 液面の高低差が小さく冷媒循環量への制 約が強いため, 万が一にサーバが傾いた場合にも冷媒が循環し，冷却できることを確認する必要があった.

著者らは，ループ式熱サイホンの傾斜角度を変えて冷却性能を測定し, 熱抵抗が凝縮部の液面位置に強く依存 していることを示した(豊田他, 2014). この際に, ある封入水量と傾斜角度の条件で泠却性能が急激に低下寸る沸 騰部のドライアウトが確認された. 沸騰面が液冷媒で濡れるように沸騰部のチャンバの底に位置していること, また, 沸騰面の熱流束が $20 \mathrm{~W} / \mathrm{cm}^{2}$ 程度と小さいことから, 本ループ式熱サイホンのドライアウトの要因が限界熱 流束によるもの(小泉他, 1994) (Hartenstine, et al., 2007) とは考え難い.

したがって, この沸騰部でのドライアウトは, 沸騰現象そのものではなく, 冷媒循環に伴う圧力損失と液へッ ドがバランスし，凝縮部側に液が溜まり，沸騰部の液がなくなるためと考えた，過去に沸騰部と凝縮部の高低差 が十分にある場合では, 冷媒循環に伴う圧力損失が計算がされている(神谷他, 1989) (Khodabandeh and Palm, 2000) (Haider, et al., 2001). しかしながら，高低差が小さい場合の圧力損失によるドライアウトと傾斜との関係について は, 十分検討されてはいない.

本報告では，沸騰部と凝縮部の高低差の小さいループ式熱サイホンを対象に，実験的にドライアウトが発生す る冷媒封入量と傾斜角度を関連付け，ドライアウトの発生要因を考察した。

\section{2. 使用記号}

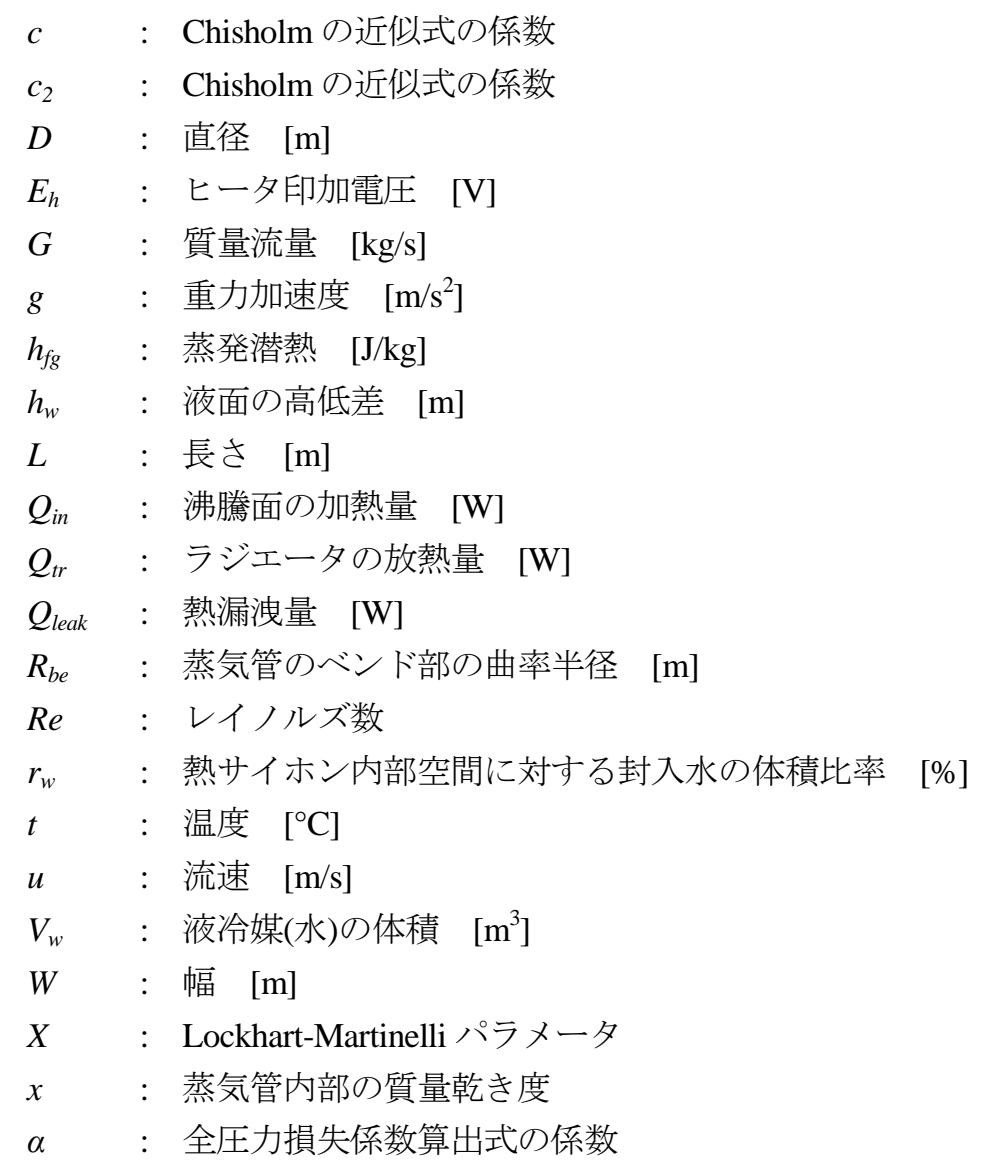



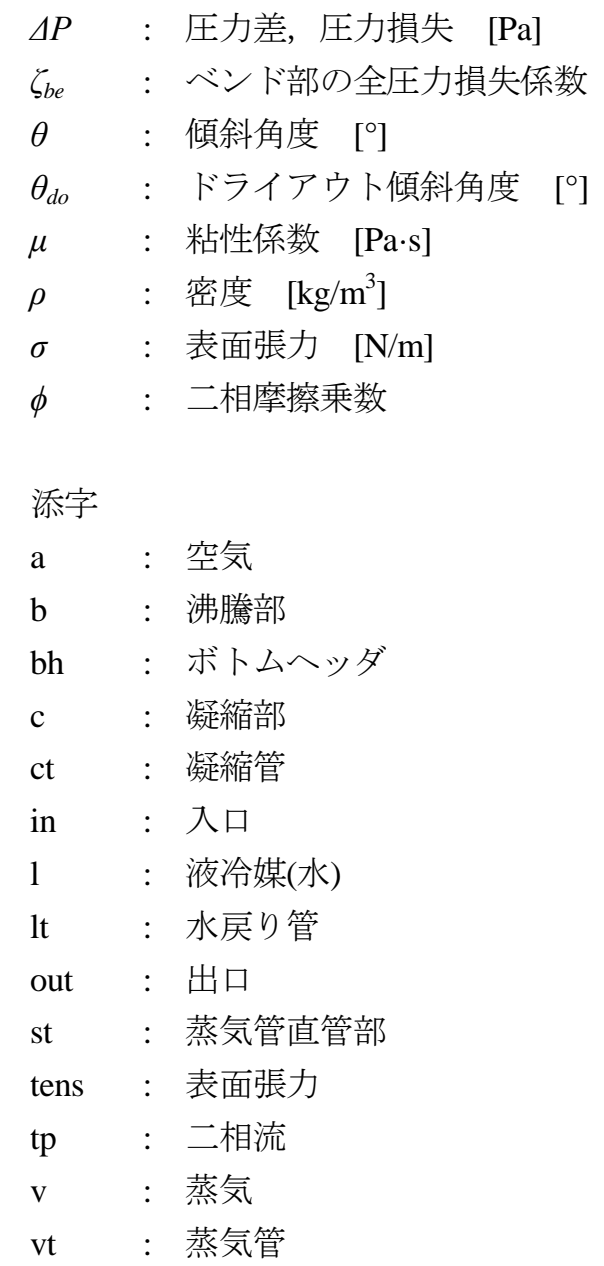

\section{3. ドライアウト発生角度の実験}

\section{$3 \cdot 1$ 実験装置}

図 1 に，実験装置の概要を示寸，実験で用いたループ式熱サイホンは，沸騰部，蒸気管，ラジエータ，水戻り 管から構成されている. 実際のサーバ冷却では, 沸騰部は熱伝導グリースを介して CPU 直上に取り付けられる. CPU の熱は, 沸騰部内の水の沸騰により除熱される. 沸騰により発生した蒸気は, ラジエータへ流れ込み, 冷却 ファンによりラジエータへ流される空気に放熱して凝縮する。凝縮した水は，ラジエータ内部と沸騰部との液面 の高低差による重力の作用で，水戻り管を通り沸騰部に戻る. 本ループ式熱サイホンは，この一連の冷媒の相変 化と循環により，CPU の熱をラジェータに効率よく輸送するとともに空気へ放熱する.

実験では，セラミックヒータを取り付けた無酸素銅製のブロックを，熱伝導グリースを介して沸騰面に接触さ せることでCPU 発熱を模擬した.

図 2 に，実験に使用したループ式熱サイホンの写真を示寸．本報告では沸騰部とラジエータ間の距離，および ラジエータ部の寸法が異なる三形状についてドライアウト傾斜角度を測定した. 図 2 の上部左側(a)が Type-1, 上 部右側(b)が Type-2, 下部左側(c)が Type-3, 下部右側(d)が Type-1 および Type-2 で使用したラジエータの構造であ る.

Type-1 を基準として Type-2 の蒸気管の直管部は，Type-1 より 4 倍長くなっている．Type-2 では，内部を可視 化できるように沸騰部，蒸気管，および水戻り管の一部をアクリルで作成した．Type-3 は，蒸気管の直管部の距 離が Type-1 とほぼ等しいが, ラジエータ部の空気の流れ方向厚さ, および扁平管のサイズが Type-1 よりも小さ

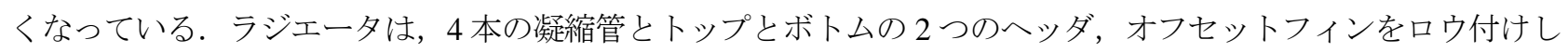
た構造である，凝縮管には，内面溝付き管の扁平管を使用した。これは，内面溝付きによる凝縮熱伝達率の向上 と，扁平化による通風抵抗の低減を活用するためである. 
アクリル部以外の材質は全て銅であり，冷媒には脱気処理した純水を用いた．図示していないが，本熱サイホ ンには，真空引き用および冷媒注入用の枝管が取り付けられ，枝管の端部にバルブを取り付けた.

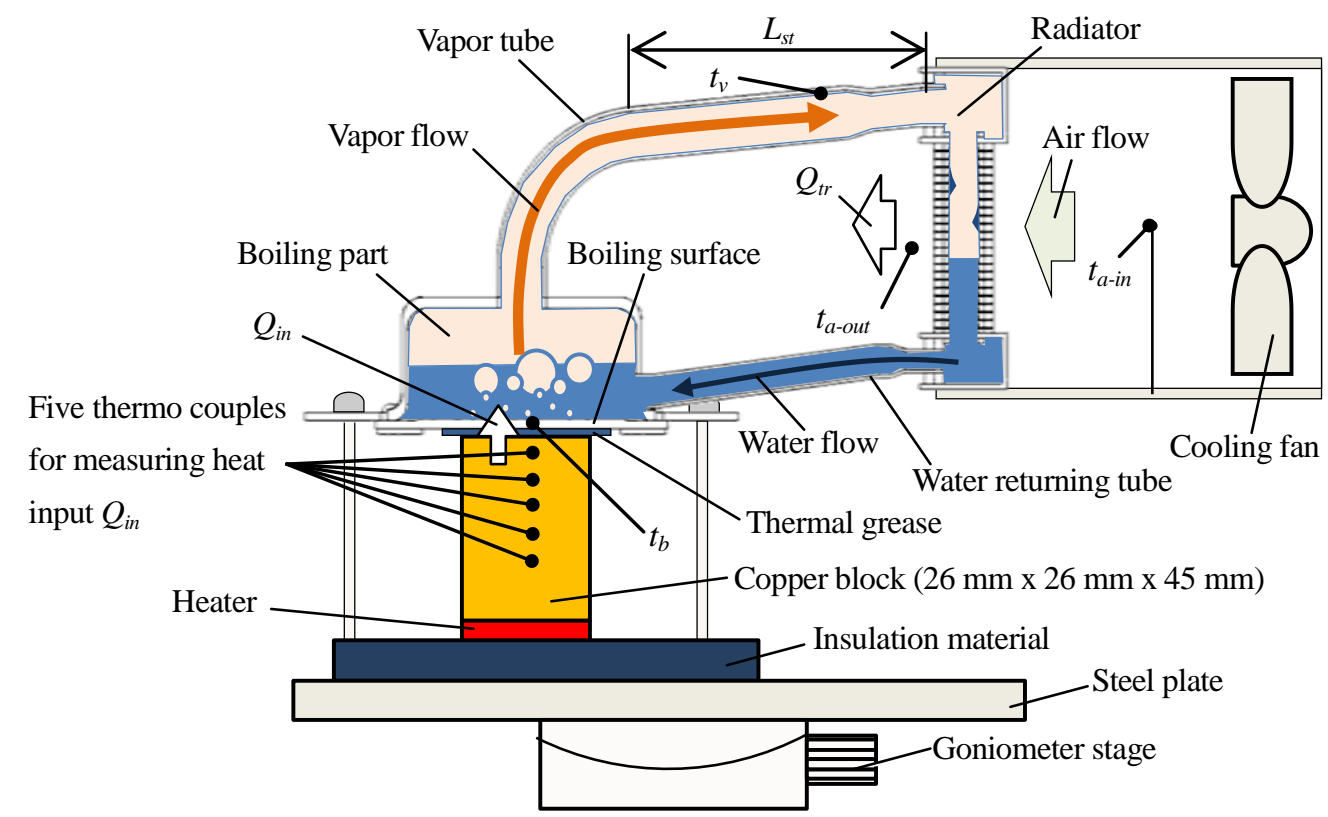

Fig. 1 Experimental apparatus and structure of loop thermosyphon.

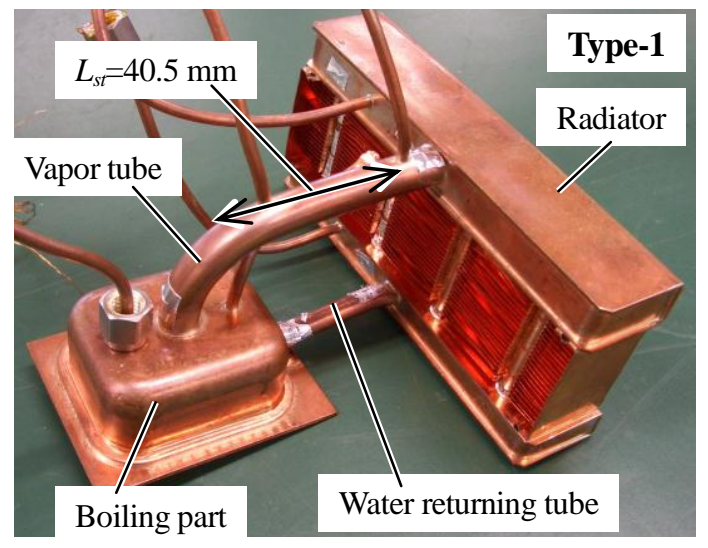

(a) Type-1

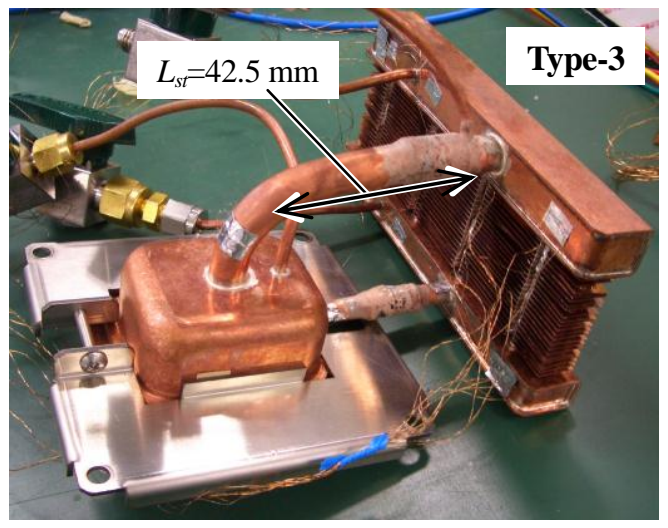

(c) Type-3

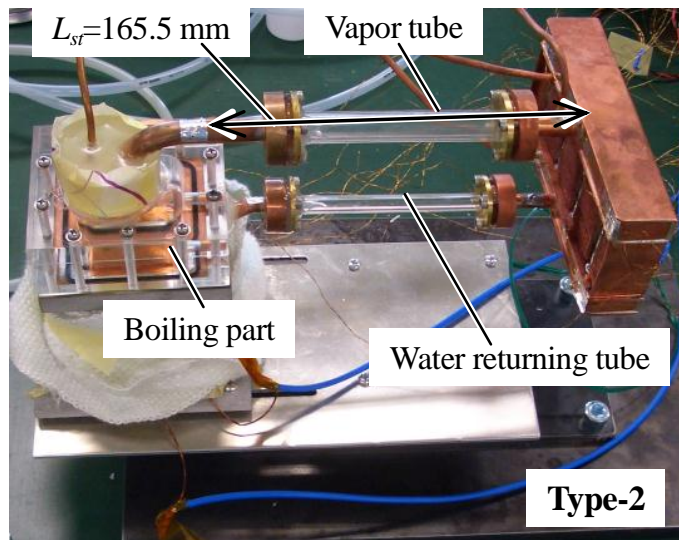

(b) Type-2

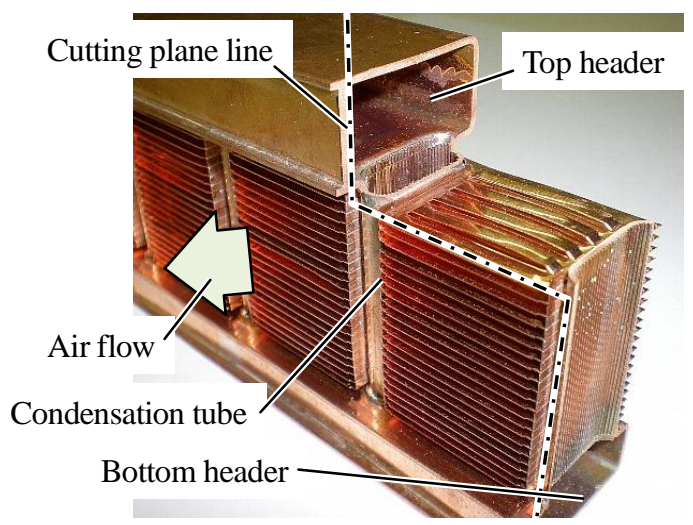

(d) Radiator in Type-1 and Type-2

Fig. 2 Photographs of tested thermosyphons. 
図 3 に本ループ式熱サイホンの断面図と各部の寸法を示す. 表 1 に形状ごとの寸法を示す. 本熱サイホンの高 さは，沸騰部底面からラジエータ上面までの距離で定義し， $67.4 \mathrm{~mm}$ と共通である．傾斜角度は，水平位置を基 準とし，ラジエータが沸騰部よりも下側となる回転方向を正とした.

沸騰部には表面を機械加工により多孔質化した銅材の平板部材(Nakayama, et al., 1980)を用いており，沸騰性能 を向上させている. この沸騰面の多孔質構造は, 沸騰部底面上の中央に, 高さ $1.0 \mathrm{~mm}$, 幅 $43 \mathrm{~mm}$, 奥行き $35 \mathrm{~mm}$ で形成されている．また沸騰部底面は幅 $45 \mathrm{~mm} ，$ 奥行き $37 \mathrm{~mm}$ 板厚は $1.5 \mathrm{~mm}$ である.

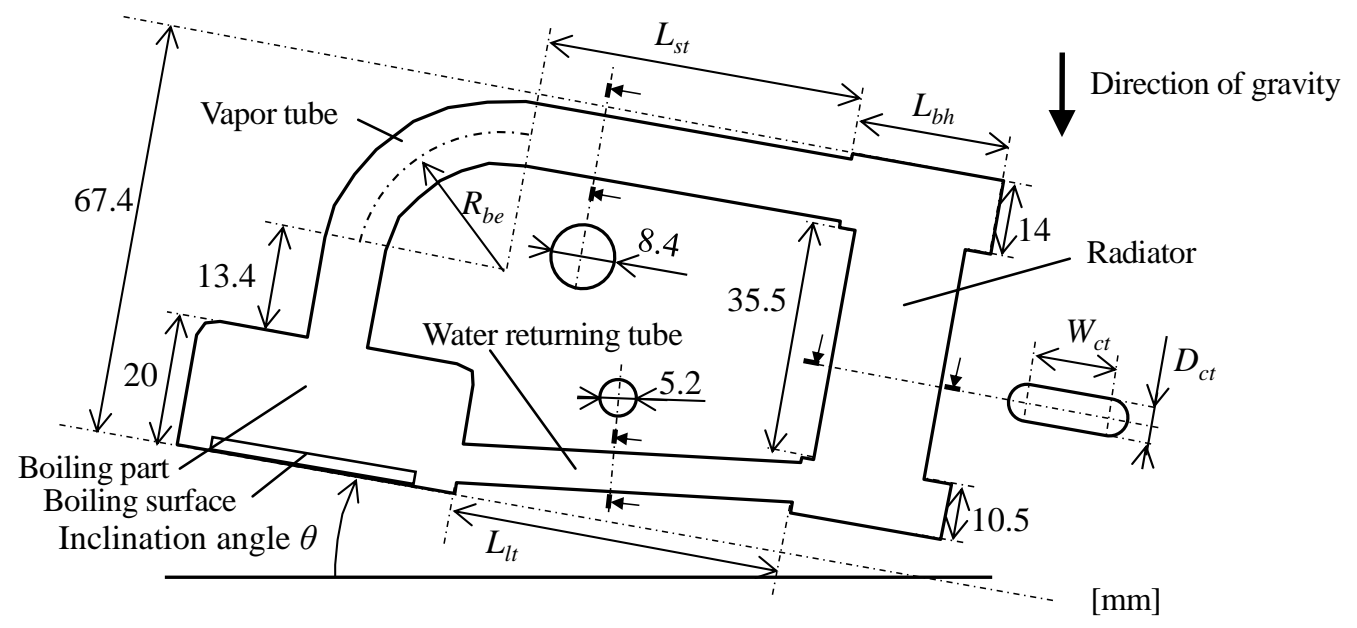

Fig. 3 Configuration and dimensions of loop thermosyphon.

Table 1 Dimensions of test thermosyphons.

\begin{tabular}{|l|c|c|c|c|}
\hline \multicolumn{2}{|c|}{ Length [mm] } & Type1 & Type2 & Type3 \\
\hline Straight part of vapor tube & $L_{s t}$ & 40.5 & 165.5 & 42.5 \\
\hline Liquid tube & $L_{l t}$ & 37.5 & 162.5 & 39.5 \\
\hline Width of bottom header & $L_{b h}$ & \multicolumn{2}{|c|}{24.0} & 14.0 \\
\hline Thickness of condensation tube & $D_{c t}$ & \multicolumn{2}{|c|}{4.3} & 2.6 \\
\hline Width of condensation tube & $W_{c t}$ & \multicolumn{2}{|c|}{11.3} & 4.7 \\
\hline
\end{tabular}

\section{$3 \cdot 2$ 実験方法}

沸騰面の加熱量 $Q_{i n}$ は，図 1 に示した銅ブロックに等間隔に埋め込んだ 5 本の熱電対より得られた温度勾配か ら求めた．実験ではヒータ印加電圧を一定としており, 加熱量はおよそ $80 \mathrm{~W}$ となっており, 熱流束は, およそ $1.2 \times 10^{5} \mathrm{~W} / \mathrm{m}^{2}$ である.

ラジェータの泠却には $80 \mathrm{~mm}$ 角の DCファン 2 台を使用し, ダクトを用いて冷却風を流した．事前にファン回 転数と風量の関係を風洞を用いて測定し，実験では風量を $0.0067 \mathrm{~m} / \mathrm{s}$ で一定となるようにした. 実験は空調され た室内で行い，冷却風の入り口の空気温度 $t_{a-\text {-in }}$ は，およそ $25^{\circ} \mathrm{C}$ となっている.

図 1 内に示寸温度測定点の記号は $t_{b}$ が沸騰面, $t_{v}$ が蒸気管, $t_{a-\text {-out }}$ がラジエータ出口空気の温度である. 温度測 定には線径 $0.1 \mathrm{~mm}$ の $\mathrm{T}$ 型熱電対を使用し, 沸騰面以外は熱電対をアルミテープを用いて表面に固定した. 沸騰 面の温度測定には，沸騰面の裏面中央に設けた深さ $0.5 \mathrm{~mm}$ ，幅 $0.5 \mathrm{~mm}$ の溝にはんだで埋め込んだ熱電対を用い た. 沸騰面の底板厚は $1.5 \mathrm{~mm}$ であり, 深さ $0.5 \mathrm{~mm}$ の溝に埋め込んだ熱電対と, 沸騰面の多孔質構造との距離は $1.0 \mathrm{~mm}$ である.したがって, 銅ブロックからの熱流束と銅板の熱伝導率 $400 \mathrm{~W} /(\mathrm{m} \cdot \mathrm{K})$ より, 熱電対と多孔質構造の 底面との温度差を求めると $0.3 \mathrm{~K}$ となる。しかしながら, 銅ブロックより沸騰部に伝わった熱は, 沸騰部底板の熱 伝導により拡散されるため熱流束はより小さくなり, 温度差もより小さくなると考えられる. したがって, 沸騰 部裏面に埋め込んだ熱電対の温度をそのまま沸騰面温度 $t_{b}$ として使用した。 
実験装置の傾斜には，ゴニオステージを用い，傾斜角度は-5 5 から $20^{\circ}$ までの範囲を測定した．実験は，封入 水量を変化させ，傾斜角度ごとに各部の温度を測定した。手順としては，ヒータ加熱を停止した状態で傾斜角度 を変え, 後にヒータを発熱させ沸騰部の温度 $t_{b}$ が定常になるのを待ち, 定常になったところでヒータ加熱を停止 し次の傾斜角度に変更した. このとき沸騰部の温度が定常とならない最も小さい傾斜角度を, ドライアウト傾斜 角度とした。

\section{$3 \cdot 3$ 実験結果および考察}

図 4 に封入水の体積比率 $r_{w}$ が $27.6 \%$ における, Type-1 の測定温度の時間履歴を示寸. 封入水の体積比率 $r_{w}$ は, 熱サイホンの内部空間の体積に対する, 封入した水の体積比率である. 熱サイホンの内部空間体積は, Type-1 が $109 \times 10^{-6} \mathrm{~m}^{3}$, Type- 2 が $124 \times 10^{-6} \mathrm{~m}^{3}$, Type- 3 が $77.4 \times 10^{-6} \mathrm{~m}^{3}$ である. 図中の $E_{h}$ はヒータの印加電圧であり, $0.1 \mathrm{kV}$ の時間帯でヒータが発熱している. 図 4 の履歴は, 傾斜角度 $\theta$ を $10^{\circ}, 15^{\circ}, 20^{\circ}, 18^{\circ}$ と変化させた結果である. 傾斜角度 $20^{\circ}$ の時に沸騰部の温度 $t_{b}$ が急上昇したため, ヒータ加熱を停止した．このように沸騰部の温度が急激 に上昇する場合を，ドライアウトと判断した。 $18^{\circ}$ の条件においても, 沸騰部の温度 $t_{b}$ が急上昇している時間が あるが，短時間で再び定常状態に戻っていることから，完全なドライアウトとは判断しなかった．

図 5 は封入水の体積比率 $r_{w}$ が 40.4\%における Type-2 の, 図 6 は封入水の体積比率 $r_{w}$ が 19.4\%における Type-3 の測定温度の時間履歴である. 図 5 中には, ラジエータ部の熱交換量 $Q_{t r}$ もプロットしている. 熱交換量 $Q_{t r}$ は, ラジエータ入口空気温度 $t_{a-\text {-in }}$ と出口空気温度 $t_{a-\text {-out }}$ の温度差と, 冷却風量, 空気の比熱の積より求めた.

図 4, 図 5, 図6 中の破線で囲った区間で, ドライアウトが発生していると判断した. どの条件においても, ド ライアウトが発生すると, 沸騰部の温度 $t_{b}$ が上昇するとともに, 蒸気管の温度 $t_{v}$ は低下することが確認できる.

図 5 の $14^{\circ}$ の条件では, ドライアウトに伴う蒸気管の温度 $t_{v}$ の低下とともに, 熱交換量 $Q_{t r}$ が低下していることが 確認できる. このことから, 蒸気管の温度 $t_{v}$ の低下は, ドライアウトにより沸騰部で発生する蒸気量が減少し, これにより沸騰部から蒸気管およびラジエータへの熱移動量が減ったためと考えられる.

Type-1 と Type-2 に関して, 傾斜角度 $\theta$, 封入水の体積比率 $r_{w}$, そして蒸気管長さの違いによる熱サイホンの放 熱特性の違いについては前報(豊田他, 2014)にて議論しているため詳細は省略する. 傾斜角度 $\theta$, 封入水の体積比 率 $r_{w}$, そして蒸気管長さが大きい条件のほうがラジエータ内部の水位が高くなり, 沸騰部温度 $t_{b}$, 蒸気管の温度 t は高い值を示寸.これによって図4に示すType-1よりも図 5 に示寸Type-2 の方が温度が高い結果となっている. また Type-3 の熱サイホンは, ラジエータの寸法が他の 2 つり小さいため沸騰部温度 $t_{b}$, 蒸気管の温度 $t_{v}$ は高い 值となる. ただし図 6 において, 傾斜角度 $\theta$ が $0^{\circ}, 3^{\circ}, 4^{\circ}$ の結果は, 沸騰部の熱抵抗を意味する沸騰部温度 $t_{b}$ と 蒸気管の温度 $t_{v}$ の温度差が $30 \mathrm{~K}$ 近い值となっている. 測定時刻が離れたデータであるが, 図 6 には傾斜角度 $\theta$ が $-5^{\circ}$ 時の結果も併記している. このように傾斜角度 $\theta$ が- $5^{\circ}$ の結果では, 沸騰部温度 $t_{b}$ と蒸気管の温度 $t_{v}$ の温度差が $10 \mathrm{~K}$ 未満となり, Type-1, Type- 2 と同程度の值となる. このことから, 傾斜角度 $\theta$ が $0^{\circ}, 3^{\circ}, 4^{\circ}$ の条件では, 沸 騰部は，水が不足しドライアウトに近い状態であると考えられる.

またどのドライアウト発生条件においても，ヒータ加熱を停止した後に蒸気管の温度 $t_{v}$ が急激に上昇する現象 が確認できる. Type-2 の可視化により, ヒータ加熱時にはラジエータ側に溜まっていた水が, ヒータ加熱停止後 に沸騰部に流れ込むことを確認している. 流れ込んだ水が, 沸騰部の熱容量によって加熱され蒸気が発生し, こ の蒸気が蒸気管を加熱したためと考えられる.この現象は，ヒータ加熱が停止するまで，水をラジエータ側に留 める力が作用していたことを示している，つまりドライアウトの発生時に発生蒸気量は低下寸るが，ゼロにはな らず，沸騰部とラジエータ側との間に抵抗・圧力差が生じていると考えられる.

ドライアウト発生後にヒータ発熱を継続できた場合には，最終的に熱交換量 $Q_{t r}$ がゼロとなることが予想され る. 熱交換量 $Q_{t r}$ がゼロとなると, 蒸気の流れが完全に無くなり, 沸騰部とラジエータ側の間の圧力差が無くな ると考えられる. これによりヒータ加熱停止後と同様に, 一時的に水が沸騰部に戻り, 再び蒸気が発生し熱交換 量が上昇する．そして再びドライアウトに至り熱交換量 $Q_{t r}$ が低下してゆくという周期的な現象が発生すると予 想される. 今回は, 実験装置の安全上の理由によりドライアウト発生の途中でヒータ加熱を停止したため, この ような周期現象は確認できなかった。しかし，この周期現象の発生要因や周期などが明らかとなれば，ドライア ウトによる沸騰部の温度上昇限界も予測できると考える. したがって本研究の冷却対象である CPU 冷却には適用 できないが，ドライアウトによる沸騰部温度の急激な温度上昇も許容できるような泠却対象に対しては，このド 
ライアウトの周期現象を明らかとすることでループ式熱サイホンを用いる際の傾斜角度や封入推量の適用可能範 囲を広げることが可能となると考える.

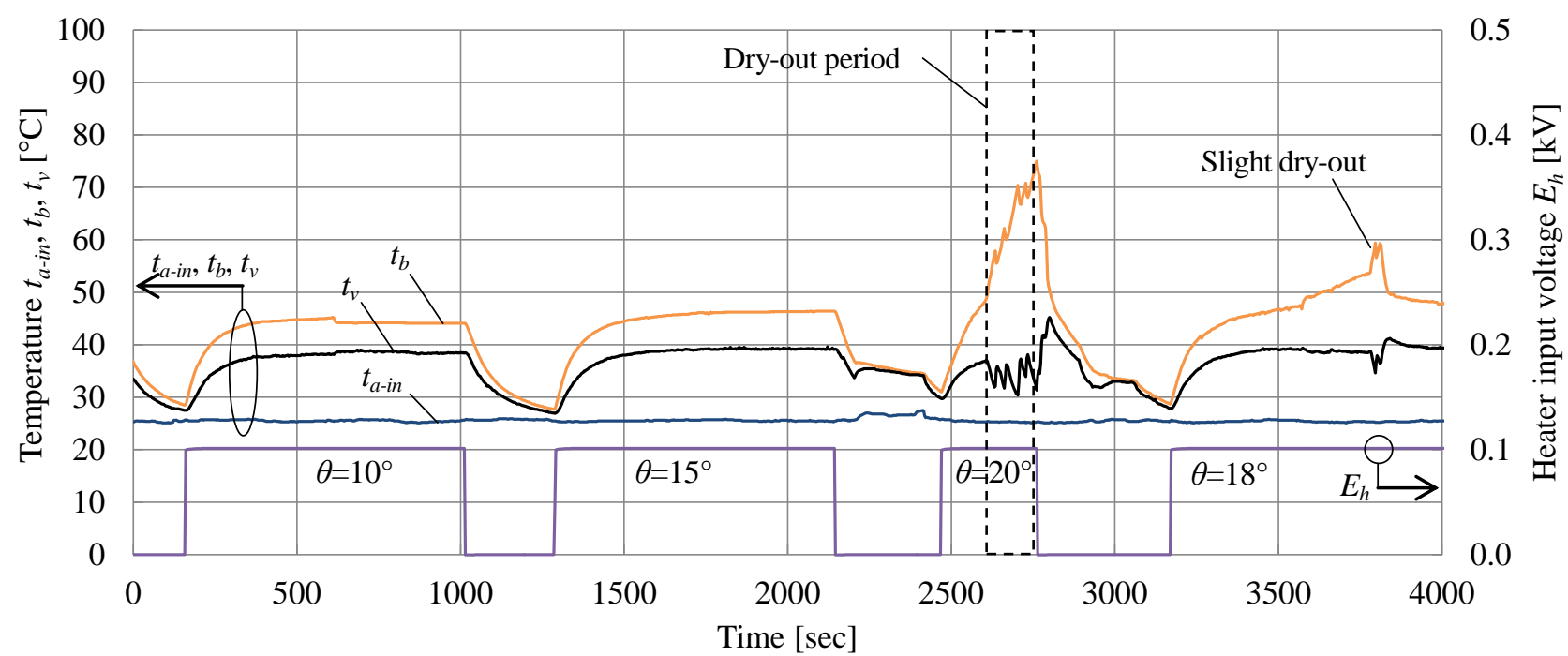

Fig. 4 Temperature history of Type-1 $\left(r_{w}=27.6 \%\right)$.

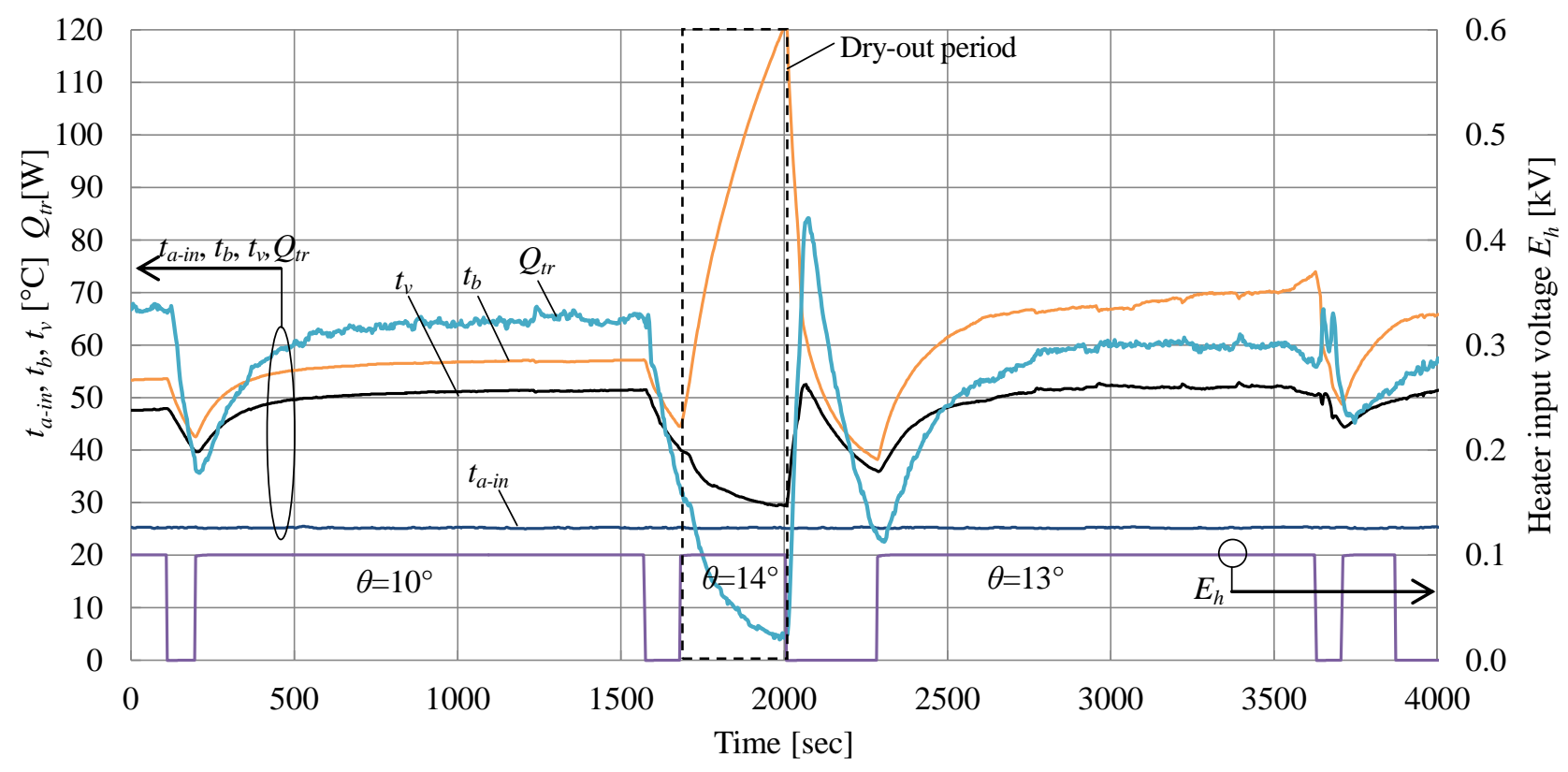

Fig. 5 Temperature history of Type-2 $\left(r_{w}=40.4 \%\right)$. 


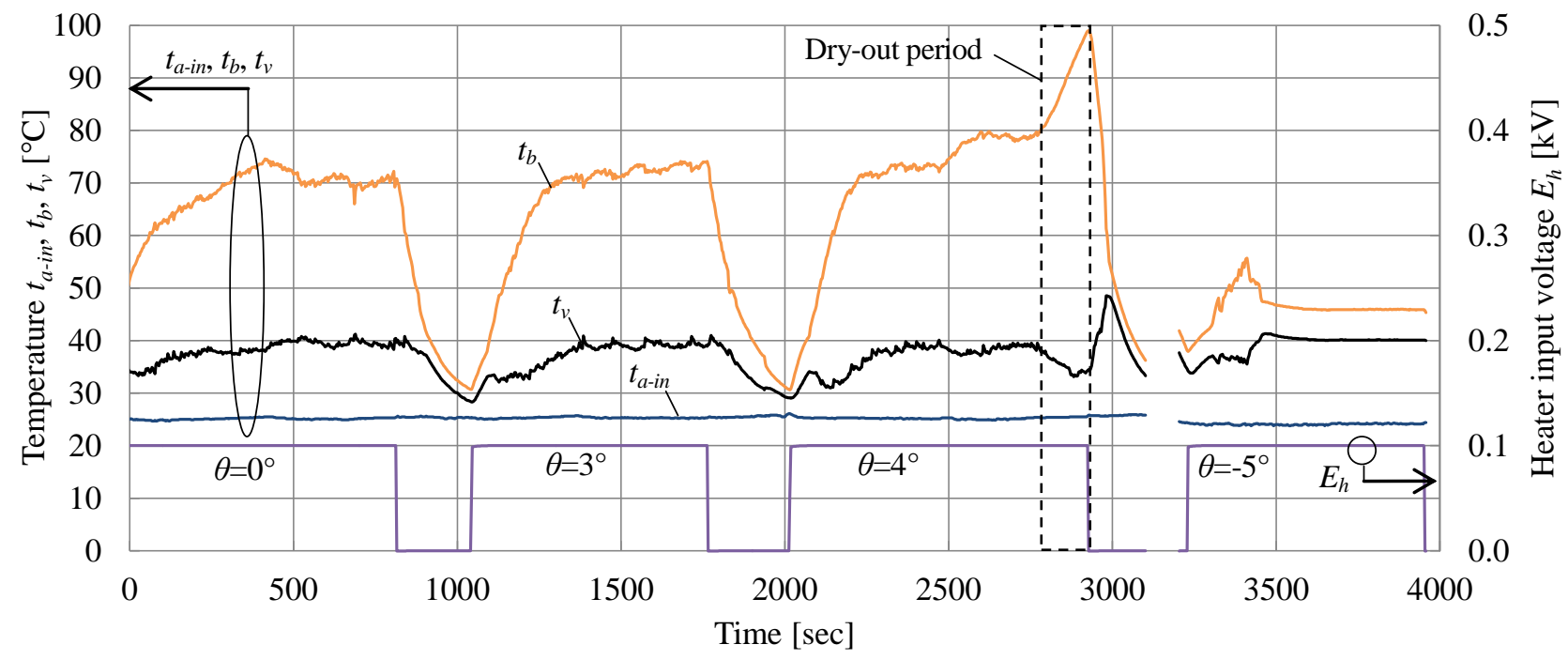

Fig. 6 Temperature history of Type-3 $\left(r_{w}=19.4 \%\right)$.

図 7 は，Type-2 の蒸気管の可視化写真である，蒸気管には，凝縮した水滴が付着しており，また不規則に沸騰 部から流れ込む大きな水塊により流されることを確認した。これらの水滴の滞留は, ラジエータ側の水量の減少 や，蒸気管部での圧力損失の増大を伴うため，ドライアウトが発生しや寸くなる要因と考える．また蒸気管内で 蒸気の凝縮が発生していることからも, ラジエータ部以外からの熱漏洩量 $Q_{\text {leak }}$ が存在することが確認できる.

図 8 に, Type-2 の沸騰部の可視化写真を示寸. 左の写真(a)は封入水の体積比率 $r_{w}$ が $40.4 \%$, 傾斜角度 $\theta$ が $5^{\circ}$ の 満水状態を, 右の写真(b)は, ドライアウトに近い封入水の体積比率 $r_{w}$ が $32.3 \%$, 傾斜角度 $\theta$ が $6^{\circ}$ の水が少ない 状態での沸騰を示寸．またドライアウト発生時には沸騰部での水が非常に少なくなり，ドライアウトの原因が沸 騰部での液冷媒不足によることを確認している.

図 9 は, ドライアウト角度 $\theta_{d o}$ を封入水の体積比率 $r_{w}$ ごとにプロットしたものである. 図より, 封入水の体積 比率 $r_{w}$ の増加に伴いドライアウト角度 $\theta_{d o}$ も大きくなり, ドライアウトが生じにくくなることがわかる. また, 同じ封入水の体積比率 $r_{w}$ でドライアウト発生角度 $\theta_{d o}$ を比べると, Type-3 がもっともドライアウト発生角度 $\theta_{d}$ が 大きく, ついで Type-1, Type-2の順となっている. Type-2 でドライアウト発生角度 $\theta_{d o}$ が小さい要因として, 沸 騰部とラジエータ間の距離が長いため同じ傾斜角度 $\theta$ でもラジエータの高さ位置が大きく変化すること, 蒸気管 部の圧力損失が大きいことが考えられる.

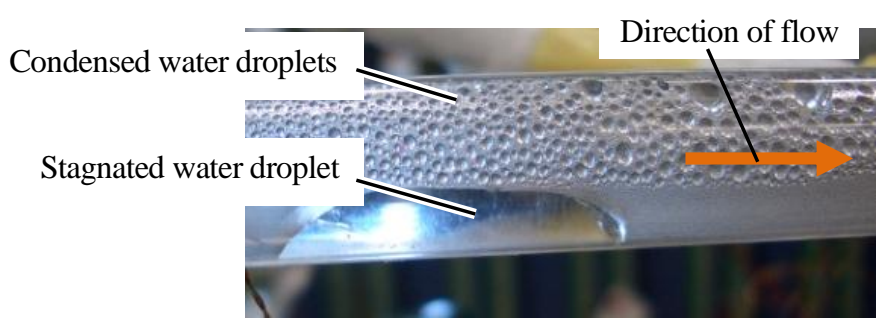

Fig.7 Visualization of water in vapor tube in Type-2 $\left(r_{w}=28.3 \%, \theta=0^{\circ}\right)$. 


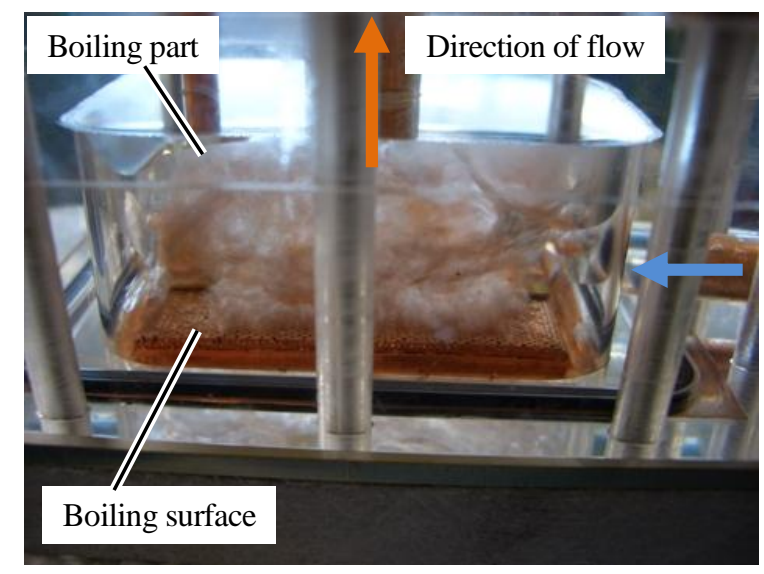

(a) $r_{w}=40.4 \%, \theta=5^{\circ}$

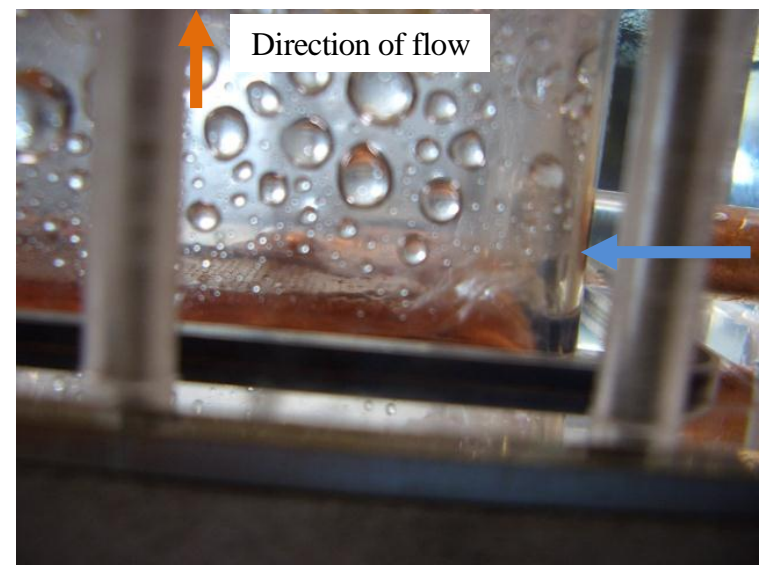

(b) $r_{w}=32.3 \%, \theta=6^{\circ}$

Fig. 8 Photographs of water in the boiling part in Type-2.

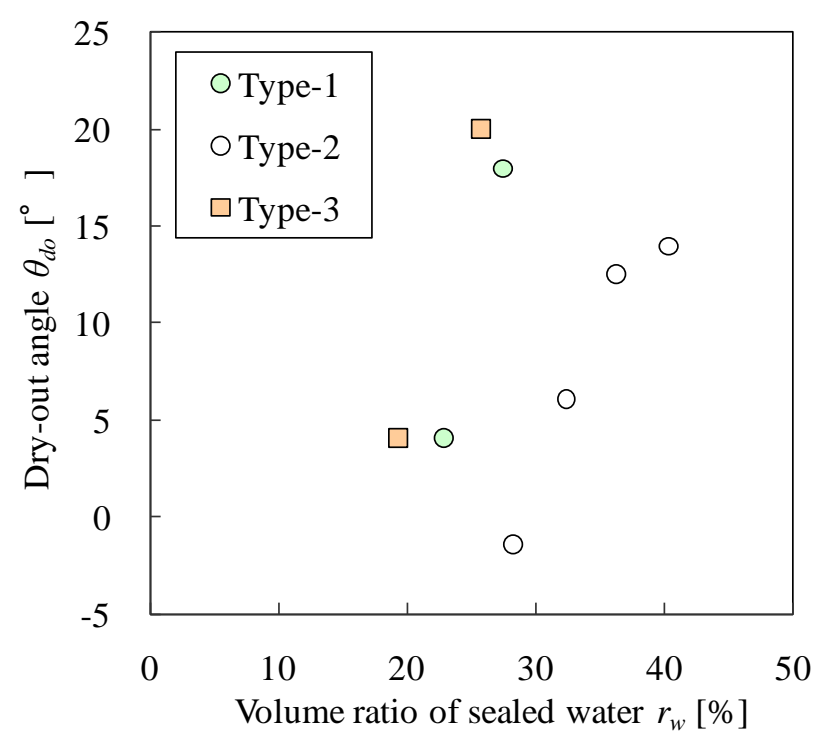

Fig. 9 Dry-out angles $\theta_{d o}$ vs. volume ratio of sealed water $r_{w}$

\section{4. ドライアウトのモデル化}

\section{$4 \cdot 1$ 蒸気管の圧力損失の計算}

実験結果より，ヒータ発熱時には凝縮部に水を留める抵抗・圧力差が作用していることが確認された。この圧 力差を把握するため, 冷媒循環に伴う圧力損失を計算した，圧力損失の計算は，神谷ら(神谷他, 1989)の場合と同 様，Lockhart-Martinelli パラメータより，Chisholm の二相摩擦乗数の近似式を用いた．ただし，循環する蒸気の 質量乾き度 $x$ を熱サイホン内部から外部への熱漏洩量 $Q_{\text {leak }}$ から得てモデル化した点と, 熱輸送量が小さいことに 伴い，蒸気，水ともに流れを層流でモデル化した点が異なる.

計算では，蒸気管の直管部とベンド部の二相流の圧力損失のみを考慮した．熱サイホン全体の圧力損失は，こ の他にも，沸騰部での加速損失，沸騰部から蒸気管上端までの位置損失，沸騰部と蒸気管の接続部における縮小 損失, 蒸気管とラジェータ接続部での拡大損失, 凝縮部での流動損失, そして水戻り管の圧力損失が考えられる. しかしこれらの值は, 蒸気管の直管部とベンド部のみの圧力損失に対して $2 \%$ 未満であるため無視した. 水と蒸 気の物性值は，蒸気温度の関数で近似したものを用いた。

以下に計算方法の詳細を述べる. 循環量 $G$ は, 沸騰面加熱量 $Q_{i n}$ と水の蒸発潜熱 $h_{f g}$ から式(1)で求めた. ここで 沸騰面加熱量 $Q_{i n}$ は測定值から約 $80 \mathrm{~W}$ 一定とした. 熱サイホン内部から外部への熱漏洩量 $Q_{\text {leak }}$ は, 前報(豊田他, 
2014)で求めた定数 8.894 を用いて, 蒸気温度 $t_{v}$ と冷却空気の入口温度 $t_{a-i n}$ の温度差, また空気の風量 $u_{a}$ に比例す ると仮定して式(2)で近似した. 蒸気の質量乾き度 $x$ は, 熱漏洩量 $Q_{\text {leak }}$ 分の蒸気が凝縮するものとし式(3)で求めた.

$$
\begin{aligned}
& G=Q_{i n} / h_{f g} \\
& Q_{\text {leak }}=8.894\left(t_{v}-t_{a-i n}\right) \cdot u_{a}^{0.6} \\
& x=\left(Q_{\text {in }}-Q_{\text {leak }}\right) / Q_{\text {in }}
\end{aligned}
$$

蒸気の質量乾き度 $x$ と循環量 $G$ から, 水の密度 $\rho_{l}$ および蒸気密度 $\rho_{v}$, 蒸気管内の直径 $D_{v t}$ を用いて, 蒸気管内 の見かけの液流速 $u_{l}$ と蒸気流速 $u_{v}$ を式(4)および式(5)で求めた. さらに, 水の粘性係数 $\mu_{l}$ および蒸気の粘性係数 $\mu_{v}$ より, 液側と蒸気側のレイノルズ数を式(6)および式(7)で求めた.

$$
\begin{aligned}
& u_{l}=\frac{4 G(1-x)}{\pi \rho_{l} D_{v t}{ }^{2}} \\
& u_{v}=\frac{4 G x}{\pi \rho_{v} D_{v t}{ }^{2}} \\
& \operatorname{Re}_{l}=\frac{\rho_{l} u_{l} D_{v t}}{\mu_{l}} \\
& \operatorname{Re}_{v}=\frac{\rho_{v} u_{v} D_{v t}}{\mu_{v}}
\end{aligned}
$$

ここで蒸気流速 $u_{v}$ は，蒸気温度 $t_{v}$ が $35^{\circ} \mathrm{C}$ で $15.2 \mathrm{~m} / \mathrm{s}$ であるが， $70^{\circ} \mathrm{C}$ では $2.5 \mathrm{~m} / \mathrm{s}$ と大きく低下する．これは蒸 気温度 $t_{v}$ の上昇に伴い蒸気密度 $\rho_{v}$ が高くなること, さらに式(2)の熱漏洩量 $Q_{\text {leak }}$ が増え, 式(3)の蒸気の質量乾き 度 $x$ が減少することに起因する. 液流速 $u_{l}$ は, 密度 $\rho_{l}$ は変化しないが熱漏洩量 $Q_{\text {leak }}$ が増え, 蒸気の質量乾き度 $x$ が減少することから, 蒸気温度 $t_{v}$ が $35^{\circ} \mathrm{C}$ 時の $3.3 \times 10^{-5} \mathrm{~m} / \mathrm{s}$ から, $70^{\circ} \mathrm{C}$ 時の $1.6 \times 10^{-4} \mathrm{~m} / \mathrm{s}$ まで増加する.

蒸気側のレイノルズ数 $R e_{v}$ は, 最大でも蒸気温度 $t_{v}$ が $35^{\circ} \mathrm{C}$ のとき 498 , 液側のレイノルズ数 $R e_{l}$ は最大でも蒸 気温度 $t_{v}$ が $70^{\circ} \mathrm{C}$ のとき 3.19 である。このように蒸気側, 液側ともにレイノルズ数が 1000 未満であることから流 れを層流とみなし， Lockhart-Martinelli パラメータ Xを式(8)のように求めた(Lockhart and Martinelli, 1949).

$$
X^{2}=\frac{1-x}{x} \cdot \frac{\rho_{v}}{\rho_{l}} \cdot \frac{\mu_{l}}{\mu_{v}}
$$

蒸気管の直管部の圧力損失 $\Delta P_{t p-s t}$ は式(9)で求めた．液単相の場合の圧力損失 $\Delta P_{l-s t}$ は，一般的な管摩擦の式(10) で求める. 式(10)中の $L_{s t}$ は蒸気管の直管部の長さ, $D_{v t}$ は蒸気管内の直径, 0.0134 は沸騰部と蒸気管ベンド部を結 ぶ直管部の長さである. 二相摩擦乗数 $\phi_{l-s t}$ は Chisholm の近似式 (11)で求めた.

$$
\Delta P_{t p-s t}=\phi_{l-s t}^{2} \Delta P_{l-s t}
$$




$$
\begin{aligned}
& \Delta P_{l-s t}=\left(\frac{64}{\operatorname{Re}_{v}}\right)\left(\frac{L_{s t}+0.0134}{D_{v t}}\right)\left(\frac{1}{2} \rho_{l} u_{l}^{2}\right) \\
& \phi_{l-s t}^{2}=1+\frac{5}{X}+\frac{1}{X^{2}}
\end{aligned}
$$

蒸気管の $90^{\circ}$ ベンド部の圧力損失 $\Delta P_{t p-b e}$ は, 液単相の場合の圧力損失 $\Delta P_{l-b e}$ にベンド部の二相摩擦乗数 $\phi_{l-b e}$ を乗 じて式(12)で求めた(日本機械学会編,1979). 液単相の場合の圧力損失 $\Delta P_{l-b e}$ は, ベンド部の全損失係数 $\zeta_{b e}$ を用いて 式(13)で求めた. このベンド部の全損失係数 $\zeta_{b e}$ には, 式(14)を用いた. ここで係数 $\alpha$ はベンド部の形状による值 であり，図 3 のベンド部の曲率半径 $R_{b e}$ から式(15)で求めた.

ベンド部の二相摩擦乗数 $\phi_{l-b e}$ は Lockhart-Martinelli パラメータX より, Chisholm のベンド管に対する近似式(16) から求めた. 式(16)中の気液の密度比を補正する係数 $c$ を式(17)で求めた. 式(17)中の $c_{2}$ は式(18)で定義される係 数である.ここで $L_{b e}$ はベンド部の中心長さである.

$$
\begin{aligned}
& \Delta P_{t p-b e}=\phi_{l-b e}{ }^{2} \cdot \Delta P_{l-b e} \\
& \Delta P_{l-b e}=\zeta_{b e} \cdot \frac{1}{2} \rho_{l} \cdot u_{l}^{2} \\
& \zeta_{b e}=0.00873 \cdot \alpha \cdot\left(\frac{64}{\operatorname{Re}_{l}}\right) \cdot \theta_{b} \cdot\left(\frac{2 R_{b e}}{D_{v t}}\right) \\
& \alpha=0.95+17.2\left(\frac{2 R_{b e}}{D_{v t}}\right) \\
& \phi_{l-b e}^{2}=(1-x)^{2} \cdot\left[1+\frac{c}{X}+\frac{1}{X^{2}}\right] \\
& c=\left[1+\left(c_{2}-1\right) \cdot\left(1-\frac{\rho_{v}}{\rho_{l}}\right)^{0.5}\right] \cdot\left[\left(\frac{\rho_{l}}{\rho_{v}}\right)^{0.5}+\left(\frac{\rho_{v}}{\rho_{l}}\right)^{0.5}\right] \\
& c_{2}=1+35 \cdot \frac{L_{b e}}{D_{v t}}
\end{aligned}
$$

以上から, 式(9)の蒸気管の直管部の圧力損失 $\Delta P_{t p-s t}$ と, 式(12)のベンド部の圧力損失 $\Delta P_{t p-b e}$ の和より, 各形状の 蒸気管の圧力損失 $\Delta P_{v t}$ を式(19)として求めた.

$$
\Delta P_{v t}=\Delta P_{t p-s t}+\Delta P_{t p-b e}
$$

図 10 には, 蒸気温度 $t_{v}$ に対する蒸気の質量乾き度 $x$ と蒸気管の圧力損失 $\Delta P_{v t}$ の計算結果を示す. ここで Type-1 と Type-3 は值が近いため重なって表示されている.

図 10 に示すように, 蒸気温度 $t_{v}$ が高いほど, 質量乾き度 $x$ と蒸気管の圧力損失 $\Delta P_{v t}$ が低くなることがわかる. 寸なわち蒸気温度 $t_{v}$ が高いと熱漏洩量 $Q_{\text {leak }}$ が高くなり, 蒸気管での凝縮量が増加するため乾き度 $x$ が小さくなる. 
図 10 には，Type-1 と Type-3 の蒸気管の圧力損失 $\Delta P_{v t}$ と, Type-2 の蒸気管の圧力損失 $\Delta P_{v t}$ を実線にて示す. また, Type-1, Type-2, およびType-3 共通のベンド部の圧力損失 $\Delta P_{t p-b e}$ を 2 点鎖線にて示す. 図 10 よりベンド部 の圧力損失 $\Delta P_{t p-b e}$ は，蒸気管の圧力損失 $\Delta P_{v t}$ の $85 \%$ から 95\%を占めており，本ループ式熱サイホンの形状におい ては，ベンド部の形状が蒸気管の圧力損失 $\Delta P_{v t}$ の支配因子であることがわかる．したがって，蒸気管の直管部長 さ $L_{s t}$ が Type-1 で $40.5 \mathrm{~mm}$ に対し, Type- 2 の蒸気管の直管部長さ $L_{s t}$ は $165.5 \mathrm{~mm}$ と 4 倍程度異なるが, 圧力損失と しては Type-1 の圧力損失に対して差は 10\%程度と小さい.

図 10 に示すように, 蒸気管の圧力損失 $\Delta P_{v t}$ は蒸気温度 $t_{v}$ 上昇に伴って低下寸る.この要因としては, 蒸気温 度 $t_{v}$ 上昇に伴って, 熱漏洩量 $Q_{\text {leak }}$ が増加し蒸気が液化することで蒸気流量が減ること, および蒸気密度の増加に より蒸気流速が減少することが考えられる. 図 10 中の破線は, Type-2の圧力損失の計算において熱漏洩量 $Q_{\text {leak }}$ を蒸気温度 $t_{v}=35^{\circ} \mathrm{C}$ 時の值である $4.4 \mathrm{~W}$ 一定とした計算結果である. つまり, 式(3)に示旂量乾き度 $x$ を蒸気温 度 $t_{v}=35^{\circ} \mathrm{C}$ 時の值である 0.95 一定とした圧力損失を示している. 実線で示寸乾き度の低下を考慮した圧力損失の 值に対して，破線で示寸乾き度を一定とした圧力損失の方が，蒸気管の圧力損失 $\Delta P_{v t}$ が低いことから，蒸気密度 の増加による蒸気流速の減少が, 圧力損失 $\Delta P_{v t}$ が蒸気温度 $t_{v}$ 上昇に伴って低下寸る要因として支配的であること がわかる，むしろ乾き度の低下により，破線に対して，実線で示寸圧力損失のほうが増加していることから，蒸 気温度 $t_{v}$ の上昇に伴う質量乾き度 $x$ の減少は, 蒸気管の圧力損失 $\Delta P_{v t}$ の増加要因となっていると言える.

ドライアウト発生時には，沸騰部での沸騰による伝熱量が低下寸るため，沸騰面の温度 $t_{b}$ が上昇する．これに 伴って熱伝導により沸騰部の容器表面温度が上昇し, 容器表面から熱サイホン周囲空気への熱漏洩量が増加する. これにより沸騰部から凝縮部へ移動する蒸気の質量流量が減り, 圧力損失が低下寸るため, 最終的には凝縮部に 留まっていた水が沸騰部へ戻ることが予想される. しかし, 図4 から図6に示したドライアウト区間では水戻り が確認できなかった. これは, 図 10 の計算結果が示寸ように蒸気温度の低下が圧力損失の増加につながるため, 熱漏洩量の増加により蒸気の質量流量が低下しても，蒸気温度も低下寸るため圧力損失がそれほど低下しないこ とによると考える.

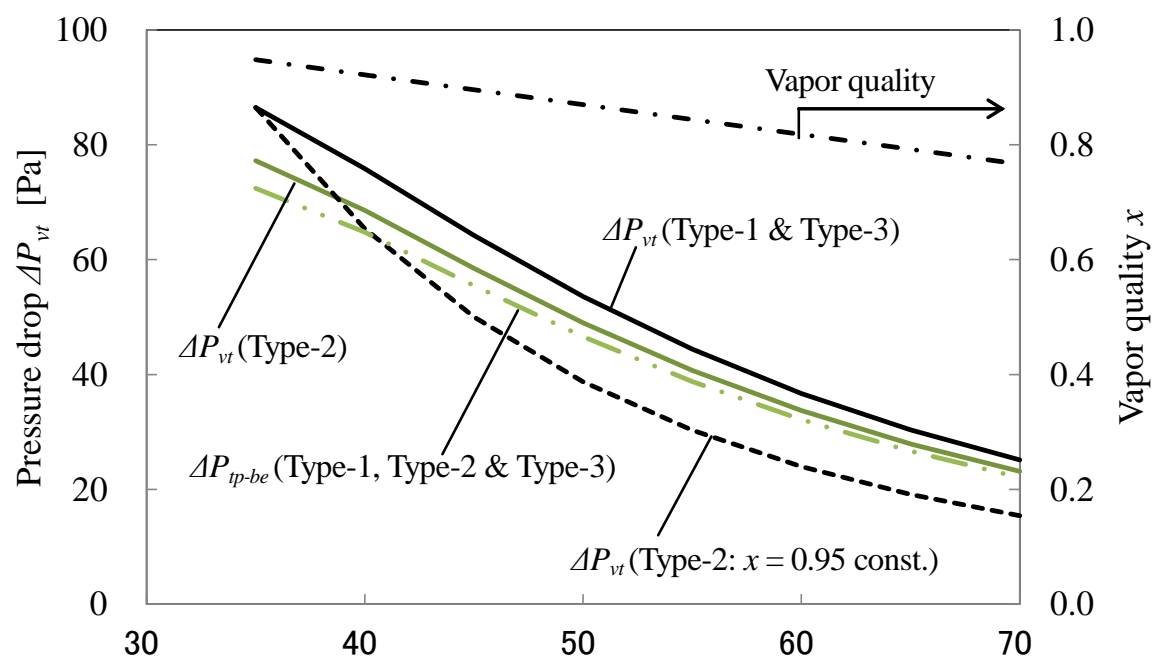

Vapor temperature $t_{v}\left[{ }^{\circ} \mathrm{C}\right]$

Fig. 10 Estimated pressure drop of vapor tube $\left(Q_{i n}=80 \mathrm{~W}, t_{a-i n}=25^{\circ} \mathrm{C}, u_{a}=0.0067 \mathrm{~m}^{3} / \mathrm{s}\right)$.

\section{$4 \cdot 2$ ドライアウト角度の予測モデル}

図 5 の実験結果より, 実際のドライアウト発生時には, 蒸気温度 $t_{v}$ が低下し, ラジエータの熱交換量 $Q_{t r}$ が減 少することが確認された．計算では，式(2)に示したように熱漏洩量 $Q_{\text {leak }}$ を蒸気温度 $t_{v}$ と冷却空気の入口温度 $t_{a-\text {-n }}$ の温度差に比例するとしており, 蒸気温度の低下は熱漏洩量 $Q_{\text {leak }}$ の減少とラジエータの熱交換量 $Q_{t r}$ の増加につ ながる，したがって本計算モデルは，ドライアウト直前までの圧力損失を見積もるものであり，ドライアウト発 
Toyoda, Kondo, Sato, Tsubaki and Hirasawa, Transactions of the JSME (in Japanese), Vol.80, No.820 (2014)

生後の圧力損失を見積もるには適していない。しかしながら，ドライアウト発生角度を予測するためには，ドラ イアウト直前の熱サイホン内部の圧力差が重要であるため, 以下，本計算モデルを用いて検討した.

図 11 は, ドライアウト時における, 本ループ式熱サイホンの内部の水分布をモデル化した図を示す.ここでは, 熱サイホンを沸騰部，蒸気管部，凝縮部の三つに分割しており，沸騰部の水量がゼロとなった状態をドライアウ トとする，凝縮部は，トップヘッダ，凝縮管，ボトムヘッダ，水戻り管を含む．ドライアウト時に，凝縮水は水 戻り管を満たすように存在するものと仮定した.

水戻り管内において，沸騰部側の端の液面は，沸騰部と水戻り管の接続部にあり，この液面において表面張力 $\Delta P_{\text {tens }}$ が生じていると仮定した。. また, 水戻り管と沸騰部の接続部の中心位置は, 沸騰面から $4.5 \mathrm{~mm}$ オフセット している. 式(20)に示すように, この中心位置から凝縮管側の液面まで液面差 $\Delta h$ により生じる圧力へッドに対し て, 蒸気管の圧力損失 $\Delta P_{v t}$ と, 水戻り管端部での表面張力による保持力 $\Delta P_{\text {tens }}$ の和が釣り合うとした. この表面 張力による保持力 $\Delta P_{\text {tens }}$ は, 水戻り管の直径 $D_{l t}=5.2 \mathrm{~mm}, 35^{\circ} \mathrm{C}$ 時の水の表面張力 $\sigma=0.07 \mathrm{~N} / \mathrm{m}$, 水戻り管と水の 接触角を $60^{\circ}$ として, 式(21)を用いて $26.9 \mathrm{~Pa}$ と求めた值を一定值として使用した.

$$
\begin{aligned}
& \rho_{l} g \Delta h=\Delta P_{v t}+\Delta P_{c a p} \\
& \Delta P_{\text {tens }}=\frac{4 \sigma \cos 60^{\circ}}{D_{l t}}
\end{aligned}
$$

式(20)より凝縮部の液面上昇量 $\Delta h$ が求まれば, 図 11 の静的な液面モデルより, 幾何学的に凝縮部の水量 $V_{w-c t}$ が求められる. 蒸気管部に滞留する水量 $V_{w-v t}$ をゼロとして, 傾斜角度 $\theta$ において熱サイホンに封入した水量がこ の凝縮部の水量 $V_{w-c t}$ よりも少ないとき, 沸騰部に水を確保できずドライアウトが発生すると考えた.

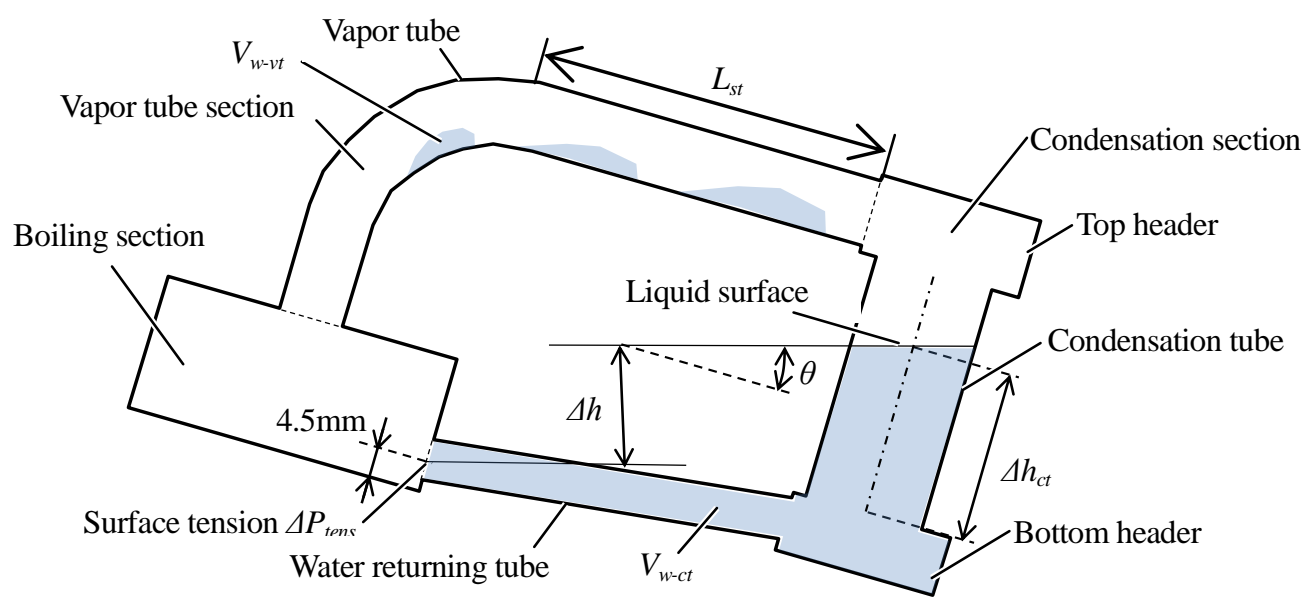

Fig. 11 Water model in loop thermosyphon

一方, 前報(豊田他, 2014)では, ラジエータ内の熱回路網モデルを用いて, 凝縮管内の液面高さ $\Delta h_{c t}$ により蒸気 温度 $t_{v}$ が求められることを示した. 図 12 は, この手法により求めた凝縮管内の液面高さ $\Delta h_{c t}$ と蒸気温度 $t_{v}$ の関係 を示す。この手法では, ラジェータ形状が同じであれば, 液面高さ $\Delta h_{c t}$ と蒸気温度 $t_{v}$ の関係は同じとなる. した がって Type-1 と Type-2 は同一の破線で表わされる。これに対して実線で示す Type-3 の蒸気温度は, 同じ凝縮管 内の液面高さ $\Delta h_{c t}$ の Type-1 と比べて, 伝熱性能が低いため高くなる. 今回のモデルでは, 図 11 の幾何的な関係 と図 12 の伝熱の関係から, 液面上昇量 $\Delta h$ と蒸気温度 $t_{v}$ を関連付けることができる. さらに, 図 10 に示した関 係から, 蒸気温度 $t_{v}$ より圧力損失 $\Delta P_{v t}$ を求め, 式(20)より凝縮部の液面上昇量 $\Delta h$ を再計算する. これを繰り返し 計算することで, 蒸気温度 $t_{v}$, 圧力損失 $\Delta P_{v}$, , 凝縮部の液面上昇量 $\Delta h$ を求めた. 


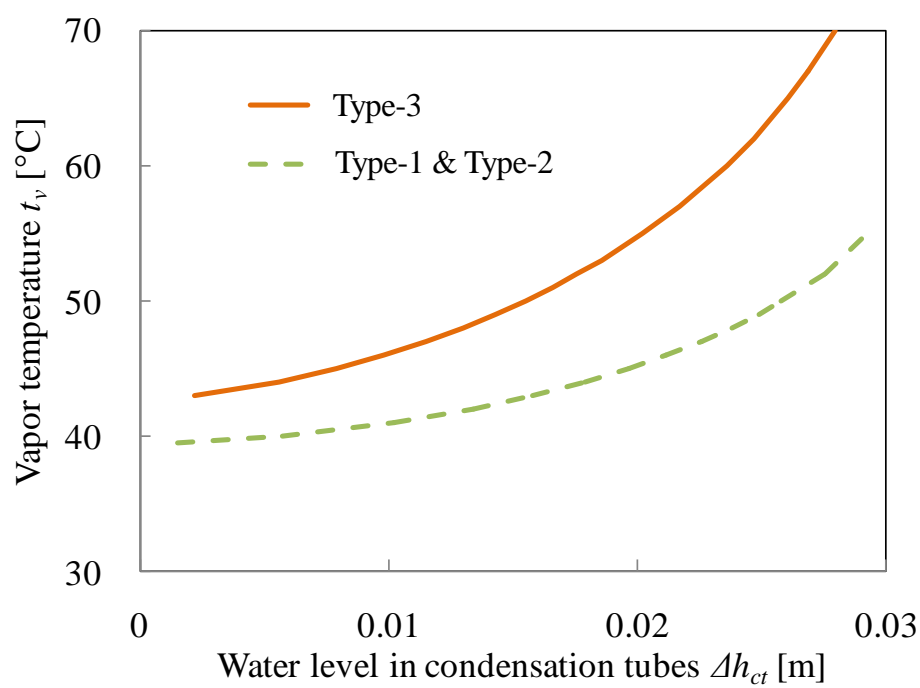

Fig. 12 Water level in condensation tube vs. vapor temperature.

図 13 に, 計算結果より得られたドライアウト傾斜角度 $\theta_{d o}$ と封入水量比 $r_{w}$ の関係を示寸. 図 13 中のプロット は図 9 の実験結果，実線と破線が計算結果である。この線よりも右下 (封入水量比 $r_{w}$ が多く，傾斜角度 $\theta_{d o}$ が小 さい) 側の条件では，ドライアウトしないことを示している。

図 13 中の実線は蒝気管部に滞留する水量 $V_{w-v t}$ をゼロとした場合の計算結果である. Type-1 および Type-3 は, 実線と実験結果がほぼ一致しているが，Type-2 は一致していない。この Type-2 の計算と実験結果の差は, 図 7 で 示したような蒸気管内に滞留する水量が反映されていないためと考えた，そこで，Type-2 の計算結果と，実験結 果が一致するように，滞留する水量 $V_{w-v t}$ をあわせた結果が図 13 中の破線である. このとき，水量 $V_{w-v t}$ を $5 \times 10^{-6}$ $\mathrm{m}^{3}$ としたとき実験結果と良く一致した．Type-2 では蒸気管内の滞留を考慮する必要があるのに対して, Type-1 およびType-3 では滞留する水量 $V_{w-v t}$ をゼロとした計算が実験と一致した要因としては, Type-1 およびType-3で は蒸気管の長さが短く, さらには銅と水との接触角がアクリルよりも小さいことで蒸気管内に滞留する水量が少 ないためと考える.

したがって，Type-1，Type-3 のように長さが短く，銅製の蒸気管部を用いた熱サイホンについては，蒸気管の 滞留する水量 $V_{w-v t}$ をゼロとして, 本計算モデルでドライアウト発生角度の傾向が得られると考えられる. また, Type-2 のような長さがあり, アクリル製の蒸気管を使用する場合には, 蒸気管に滞留する水量を考慮する必要が あると考えられる.

図 13 の計算結果は，封入水の体積比率 $r_{w}$ が実線で示寸結果は 20\%付近で，破線は 30\%付近で，ドライアウト 傾斜角度 $\theta_{d o}$ を示寸線の傾きが変化している．これは液面位置がボトムヘッダ内から凝縮管内へ移行することを 示している. 液面位置が体積の大きいボトムヘッダ内にある場合には, 液量を大きく増やさないと液面が上昇し ない，このため, 封入水の体積比率 $r_{w}$ を大きく増やさないと液面高さが変わらず, ドライアウト傾斜角度 $\theta_{d o}$ が 増加しないため，傾きが緩やかになる．これに対して凝縮管は，体積が小さく，少量の水量変化により液面高さ が変わるため，この部分では傾きが急となる．さらに Type- 2 にいては，封入水の体積比率 $r_{w}$ が 30\%以降にお いて再度傾きが緩やかになる。これは，液面がトップヘッダ内に移行したことを示している. 


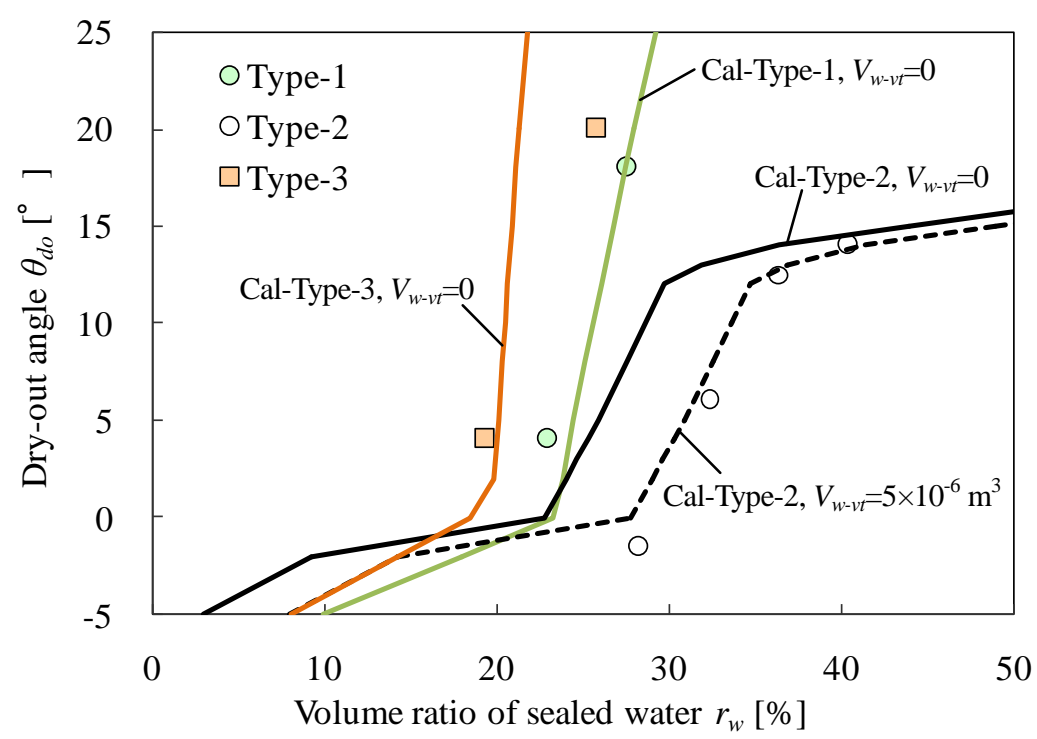

Fig. 13 Comparison of dry-out angles between calculation model and experimental results. The solid lines represent the model calculation result and the black dashed line takes into consideration the water volume in the vapor tube $V_{w-v t}$, which is assumed to be $5 \times 10^{-6} \mathrm{~m}^{3}$.

\section{$4 \cdot 3$ ドライアウト角度への形状の影響}

図 14 は，Type-2 の条件において蒝気管長さ $L_{s t}$ と圧力損失 $\Delta P_{v t}$ の計算条件を変えて，ドライアウト角度 $\theta_{d o}$ を 計算した結果であり, 実測結果も併記する.図中の破線 $\mathrm{A} 0$ は, 図 13 で示した蒸気管部に滞留する水量 $V_{w-v t}$ が $5 \times 10^{-6}$ $\mathrm{m}^{3}$ の結果である. 実線 $\mathrm{A} 1$ は，蒸気管の長さ $L_{s t}$ は $\mathrm{A} 0$ と同じだが，圧力損失 $\Delta P_{v t}$ を Type-1,Type-3 と同程度に小 さくした結果である. また圧力損失 $\Delta P_{v t}$ の式は $\mathrm{A} 0$ と同じとした条件で, 二点鎖線 $\mathrm{A} 3$ は蒸気管の長さ $L_{s t}$ を $\mathrm{A} 0$ の半分としたもの，一点鎖線 A2 は蒸気管の長さ $L_{s t}$ を $\mathrm{A} 0$ の 1.5 倍とした結果である.

図 14 の比較より, 破線 $\mathrm{A} 0$ に対して, 圧力損失 $\Delta P_{v t}$ を変えた実線 $\mathrm{A} 1$ は，それほど大きな変化はない. 蒸気管 の長さを変化させた $\mathrm{A} 2$ および $\mathrm{A} 3$ の方が， A0 に対して変化が大きい. これは蒸気管長さ $L_{s t}$ が長い方が，同じ傾 斜角度 $\theta$ でも凝縮部の高さ位置が下になりやすいためであり，この高さ位置変化がドライアウトへ強く影響する ことを示している.

図 15 は Type-3 の条件でボトムヘッダの寸法の影響を計算した結果である. 図 9 の実験結果より蒸気管の長さ $L_{s t}$ がほぼ等しい Type-1 と Type-3 のドライアウト角度 $\theta_{d o}$ の差は, ラジエータの形状によるものである. ボトムへ ッダの幅 $L_{b h}$ のみを変化させ，ボトムヘッダ容積を変えて計算を行った．ここでトップヘッダおよび扁平管の寸 法は一定とした. 実線 B0 は, 図 13 で示した Type-3 の結果である. 破線 B1 はボトムヘッダの幅 $L_{b h}$ を B0 の半分, 一点鎖線 B 2 はボトムヘッダの幅 $L_{b h}$ を倍とした結果である. 図に示すように同じドライアウト角度 $\theta_{d o}$ となる封 入水量比 $r_{w}$ は，ボトムヘッダの容量を小さくすると少なく，逆に容積が大きくすると多く必要となる．ボトムへ ッダは, 傾斜時に沸騰部よりも低い位置になりやすく満水となるうえに, 沸騰部と凝縮部の液へッド差に寄与し ない．したがってこの容積が小さくなれば，同じ封入水量であっても凝縮管の液面上昇が可能となるのでドライ アウトが発生しづらくなると考えられる. 


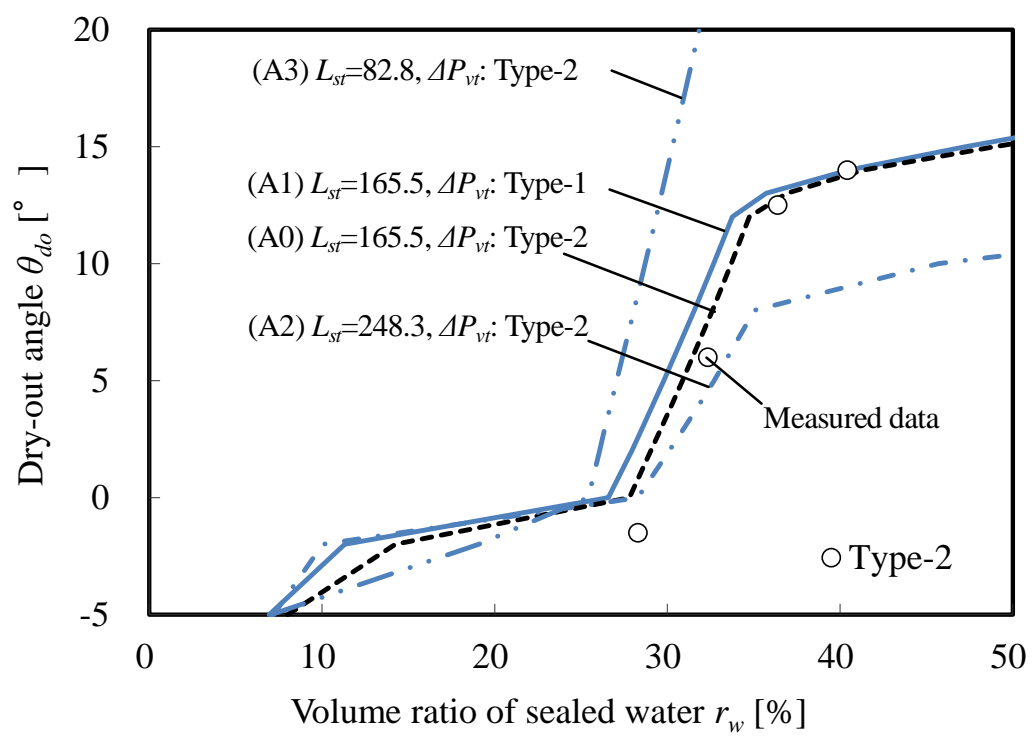

Fig. 14 Results of model calculation when changing length of vapor tube and pressure drop. The circles represent the experimental results from a Type-2 thermosyphon. Line A0 $\left(L_{s t}=165.5 \mathrm{~mm}, \Delta P_{v t}\right.$ : Type-2) is the original condition, which is the same as that in Fig 13. Line A1 $\left(L_{s t}=165.5 \mathrm{~mm}, \Delta P_{v t}\right.$ : Type-1) is in the same condition in terms of the vapor tube length as Type-2, and with a lower pressure drop as with Type-1. In addition, Lines A2 $\left(L_{s t}=248.3 \mathrm{~mm}, \Delta P_{v t}\right.$ : Type-2) and A3 $\left(L_{s t}=82.8 \mathrm{~mm}\right.$, $\Delta P_{v i}$ : Type-2) have changed vapor tube lengths.

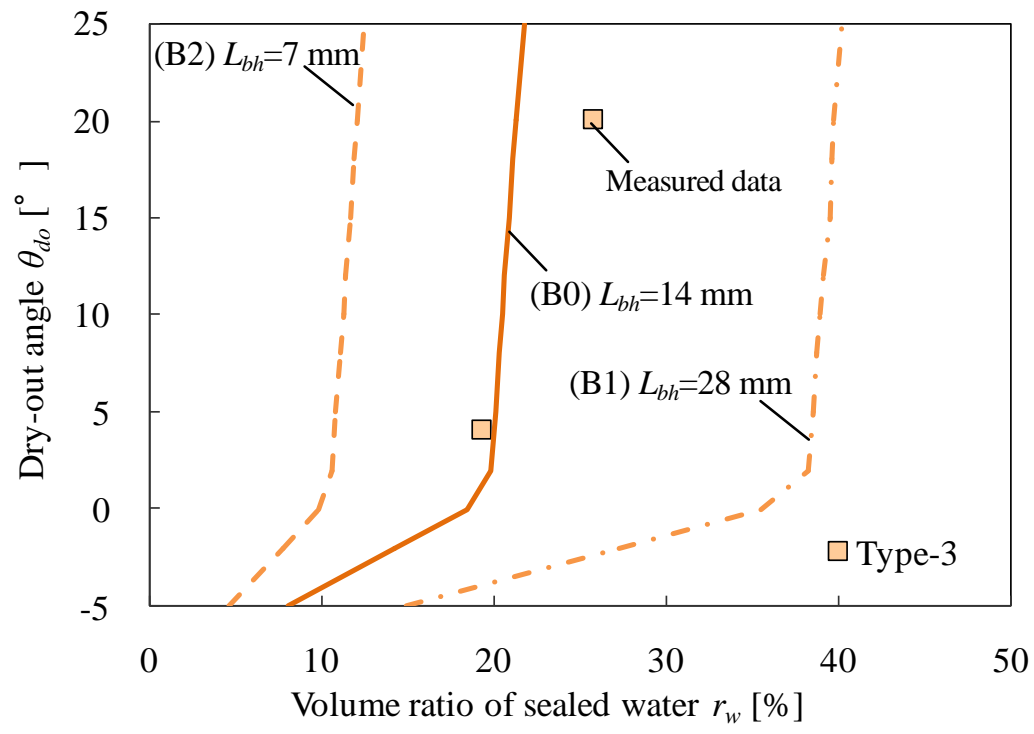

Fig. 15 Results of model calculation with changing bottom header volume. The squares represent the experimental results for a Type-3 thermosyphon. Line B0 $\left(L_{b h}=14 \mathrm{~mm}\right)$ is the original condition, which is the same as in Fig 13. Line B1 has a larger bottom header than the original, and line $\mathrm{B} 2$ has a smaller one.

\section{5. 結 言}

CPU 冷却向けとして開発した薄型のループ式熱サイホンを対象として, 沸騰部とラジェータ間の距離やラジエ ータ形状を変えた三種類のループ式熱サイホンを傾斜させ，沸騰部のドライアウトが発生する傾斜角度 $\theta_{d o}$ と封 入水量比 $r_{w}$ の関係を実験的に評価した結果, 以下の結論を得た. 
Toyoda, Kondo, Sato, Tsubaki and Hirasawa, Transactions of the JSME (in Japanese), Vol.80, No.820 (2014)

（1）ループ式熱サイホンを凝縮部が沸騰部よりも低くなるように傾斜させると沸騰部に水が戻らなくなることに よりドライアウトが発生し，その発生する傾斜角度 $\theta_{d o}$ は形状および封入水量比 $r_{w}$ にって異なる。

(2) 凝縮管内部の液面位置 $\Delta h_{c t}$ と蒸気温度 $t_{v}$ の関係(図 12), 蒸気温度 $t_{v}$ に対する蒸気管の圧力損失 $\Delta P_{v t}$ の計算, 式(20)と幾何学的な液面高さ $\Delta h$ を組夕合わせることで, ドライアウト発生角度 $\theta_{d o}$ を予測できることを示し た.

（3）実験および計算により，蒸気管が長い方が短いものより小さい傾斜角度でドライアウトが発生することを示 した．その要因は，蒸気管が長い方が同じ傾斜角度でも凝縮部の高さ位置が下になりやすいためであり，蒸 気管の長さに伴う圧力損失 $\Delta P_{v t}$ の影響が小さいことを示した。

（4）実験および計算より，ボトムヘッダの容積が小さい方が，少ない封入水量比 $r_{w}$ でもドライアウトが発生しに くいことを示した.

\section{文献}

儀間悟, 長田孝志, 張興, 藤井丕夫, 二相閉ループ型熱サイフォンによる CPU冷却に関する実験的研究, 日本機械 学会論文集 B 編 Vol.70, No.694 (2004), pp.118-123.

Haider, S. I., Joshi, Y. K. and Nakayama, W., A natural circulation model of the closed loop; two-phase thermosyphon for electronics cooling, Proceeding of 2001 ASME International Mechanical Engineering Congress and Exposition(2001), pp.209-218.

Hartenstine, J. R., Bonner III, R. W., Montgomery, J. R. and Semenic, T., Loop thermosyphon design for cooling of large area, high heat flux sources, Proceeding of ASME InterPACK 2007, IPACK2007-33993 (2007).

Inoue, T. and Monde, M., Operating limit of heat transport in two-phase thermosyphon with connecting pipe (heated surface temperature fluctuation and flow pattern), International Journal of Heat and Mass Transfer 52 (2009), pp.4519-4524.

神谷是行, Kwo C. Cheng, 田熊昌夫, 閉ループ二相流熱サイフォンを用いた空気-水熱交換器の作動特性, 空気調 和・衛生工学会論文集 Vol.41 (1989), pp.41-50.

Khodabandeh, R. and Palm, B., An experimental and numerical investigation of pressure drop in a closed loop two phase thermosyphon system, Thermal and Thermomechanical Phenomena in Electronic Systems, 2000. ITHERM 2000. The Seventh Intersociety Conference on, Vol.2 (2000), pp.333-339.

小泉安郎, 吉成考正, 植田辰洋, 松尾輝之, 宮下徹, 二相自然循環系のドライアウト熱流束に関する研究，日本機 械学会論文集 B 編 Vol.60, No.570 (1994), pp.545-551.

Lockhart, R. W. and Martinelli, R. C., Proposed correlation of data for isothermal two-phase, two-component flow in pipes, Chemical Engineering Progress Vol.41, No.1 (1949), pp.39-48.

門出政則, 光武雄一, 栗原成計, 二相熱サイフォンの限界熱流束の解析的研究 (最大流下液量と限界熱流束の関連 について），日本機械学会論文集 B 編 Vol.61, No.591 (1995), pp.4101-4108.

日本機械学会編, 技術資料 管路・ダクトの流体抵抗 (1979), pp.73-74, pp.183-190, 日本機械学会.

日本機械学会編，伝熱工学資料，改訂第 4 版 (1986), pp.52-53, pp.128-129.

豊田浩之, 近藤義広, 佐藤重匡, 椿繁裕, CPU 冷却用熱サイフォンによる省電力サーバの開発, 2011 年度日本冷凍 空調学会年次大会講演論文集(2011), pp.487-490.

豊田浩之, 近藤義広, 佐藤重匡, 椿繁裕, CPU 冷却向けループ式熱サイホンの伝熱性能に対する不凝縮ガスの影 響，日本機械学会論文集 B 編 Vol.78, No.795 (2012), pp.2030-2045.

豊田浩之, 近藤義広, 佐藤重匡, 椿繁裕, CPU 冷却向けループ式熱サイホンの傾斜時の伝熱特性, 日本機械学会論 文集 Vol.80, No.814(2014), DOI : 10. 1299/transjsme. 2014tep0154.

Webb, R. L. and Yamauchi, S., Test results on a thermo-syphon concept to high-power cool desktop computers and servers, 18th IEEE SEMI-THERM Symposium (2002), pp. 151-158.

\section{References}

Gima, S., Nagata, T., Zhang, X. and Fujii, M., An experimental study on cooling of CPU using a two phase closed thermosyphon loop, Transactions of the Japan Society of Mechanical Engineers, Series B, Vol.70, No. 694 (2004), pp.118-123 (in Japanese).

Haider, S. I., Joshi, Y. K. and Nakayama, W., A natural circulation model of the closed loop; two-phase thermosyphon for electronics cooling, Proceeding of 2001 ASME International Mechanical Engineering Congress and Exposition (2001), 
pp.209-218.

Hartenstine, J. R., Bonner III, R. W., Montgomery, J. R. and Semenic, T., Loop thermosyphon design for cooling of large area, high heat flux sources, Proceeding of ASME InterPACK 2007, IPACK2007-33993 (2007).

Inoue, T. and Monde, M., Operating limit of heat transport in two-phase thermosyphon with connecting pipe (heated surface temperature fluctuation and flow pattern), International Journal of Heat and Mass Transfer 52 (2009), pp.4519-4524.

Kamiya, Y., Cheng, K. C. and Takuma, M., Operating characteristics of an air-to-water heat exchanger using a closed-loop two-phase thermosyphon system, Transactions of the Society of Heating, Air-Conditioning and Sanitary Engineers of Japan, No. 41 (1989), pp.41-50 (in Japanese).

Khodabandeh, R. and Palm, B., An experimental and numerical investigation of pressure drop in a closed loop two phase thermosyphon system, Thermal and Thermomechanical Phenomena in Electronic Systems, 2000. ITHERM 2000. The Seventh Intersociety Conference on, Vol.2 (2000), pp.333-339.

Koizumi, Y., Yoshinari, T., Ueda, T., Matsuo, T. and Miyashita, T., Study on dry-out heat flux of two-phase natural circulation, Transactions of the Japan Society of Mechanical Engineers, Series B, Vol.60, No. 570 (1994), pp.545-551(in Japanese).

Lockhart, R. W. and Martinelli, R. C., Proposed correlation of data for isothermal two-phase, two-component flow in pipes, Chemical Engineering Progress Vol.41, No.1 (1949), pp.39-48.

Monde, M., Mitsutake, Y. and Kurihara, A., Analysis of critical heat flux in two-phase thermosyphon (relationship between maximum falling liquid rate and critical heat flux), Transactions of the Japan Society of Mechanical Engineers, Series B, Vol.61, No.591 (1995), pp.4101-4108 (in Japanese).

The Japan Society of Mechanical Engineers ed., JSME Data Book: Hydraulic losses in pipes and ducts (1979), pp.73-74, pp.183-190 (in Japanese).

The Japan Society of Mechanical Engineers ed., JSME Data Book: Heat Transfer $4^{\text {th }}$ edition (1986), pp.52-53, pp.128-129 (in Japanese).

Toyoda, H., Kondo, Y., Sato, S. and Tsubaki, S., Development of the energy-saving servers use thermosyphons for CPU cooling, Proceedings of 2011 Japan Society of Refrigerating and Air-Conditioning Engineers Annual Conference (2011), pp.487-490 (in Japanese).

Toyoda, H., Kondo, Y., Sato, S. and Tsubaki, S., Effects of non-condensable gases on heat transfer performance of loop thermosyphon for CPU cooling, Transactions of the Japan Society of Mechanical Engineers, Series B, Vol.78, No.795 (2012), pp.2030-2045 (in Japanese).

Toyoda, H., Kondo, Y., Sato, S. and Tsubaki, S., Effects of inclination angles on heat transfer performance of a loop thermosyphon for CPU cooling, Transactions of the JSME (in Japanese), Vol.80, No.814(2014), DOI : 10. 1299/transjsme. 2014tep0154.

Webb, R. L. and Yamauchi, S., Test results on a thermo-syphon concept to high-power cool desktop computers and servers, 18th IEEE SEMI-THERM Symposium (2002), pp.151-158. 